\title{
Toxic metal amounts in Chelon auratus (Risso, I8I0): a potential risk for consumer's health
}

\begin{abstract}
In the present study, the golden grey mullet Chelon auratus (Risso, 1810) were captured from Sinop shores of the southern Black Sea coasts and analyzed for toxic metals in liver, gills and muscle tissues. Among studied toxic metals, $\mathrm{Pb}$ had highest mean concentration in gills compare to either liver or muscles. On the other hand highest amounts of $\mathrm{Hg}$ and $\mathrm{Cd}$ were observed in liver. The minimum amounts of toxic metals were found in the edible tissues. The mean amounts of $\mathrm{Pb}, \mathrm{Hg}$ and $\mathrm{Cd}$ in the edible tissues of $C$. auratus were $0.061 \pm 0.012,0.034 \pm 0.009$ and $0.015 \pm 0.008 \mathrm{mg} / \mathrm{kg}$ wet wt., respectively. It was shown that the estimated metal dose values for daily average consumption and hazard index in the edible tissues of fish samples were below safety levels for human consumption.
\end{abstract}

Keywords: toxic metals, chelon auratus, black sea, estimated daily intakes, hazard index
Volume 7 Issue 6 - 2018

Levent Bat, Fatih Șahin, Ayșah Öztekin

Department of Hydrobiology, University of Sinop, Turkey

Correspondence: Levent Bat, Department of Hydrobiology, Fisheries Faculty, University of SinopTR57000 Sinop, Turkey, Tel +90 368 2876265, Email leventbet@gmail.com

Received: October 26, 2018 | Published: November |4, 2018

\section{Introduction}

Marine pollution by toxic metals as a result of anthropogenic activities is causing major ecological problems in coastal areas of the Black Sea. ${ }^{1}$ This circumstances is intensified by the deficiency of natural elimination processes for toxic metals. Consequently, toxic metals movement from one section within the coastal waters to another, including the biota and sediment, often with harmful effects. Marine biota including fish accumulate toxic metals in their tissues and in the end kill the organisms. ${ }^{2}$ Moreover, where enough accumulation of these toxic metals in fish occurs via food chain transfer, there is an increasing health risk for people. The assessment of metal pollution is the main perspective Marine Strategy Framework Directive to protect more effectively the marine environment. ${ }^{3}$ With the ever increasing pollution in the Black Sea coasts; the risk of fish contaminated with toxic metal is increasing day by day. The current work of assessment of toxic metals in Chelon auratus was therefore intended to understand this trend.

Golden grey mullet Chelon auratus (Risso, 1810) occur widely in the Black Sea. Adult specimens are neritic usually in schools, entering lagoons and lower estuaries and rarely entering freshwater. Reproduction takes place in the sea, from July to November. Although the quality of the flesh is variable, ${ }^{4}$ they are consumed in the Black Sea coasts. The present work was thus, carried out in view of the paucity of information on toxic metals in this fish from this region. In this work, the amounts of $\mathrm{Pb}, \mathrm{Hg}$ and $\mathrm{Cd}$ in different tissues of golden grey mullet from the southern Black Sea coasts were reported. This work also aimed to compare with the literature on the levels of $\mathrm{Pb}, \mathrm{Hg}$ and $\mathrm{Cd}$ in mullet species from the Black Sea and to conduct a health risk assessment of these toxic metals attributed to consumption of this fish species available in fish markets. The results of this work will help in generating data needed for the appraisal of toxic metal intakes.

\section{Material and methods}

Golden grey mullet were captured fishing season from $1^{\text {st }}$ September to $31^{\text {st }}$ December in 2016 from Sinop shores of the southern Black Sea (Figure 1). After recording total length and wet body weight, the fish samples were washed, the entire gills, liver and dorsal tissues of golden grey mullet were dissected. The tissues were wet digested with Suprapur ${ }^{\circledR} \mathrm{HNO}_{3}$ using a microwave digestion system (Milestone Systems, Start D 260) for toxic metal analysis. Fish tissues were analyzed by an ICP-MS (Inductively Coupled Plasma-Mass Spectrometer) with TORT-3 lobster hepatopancreas standard reference material for the analysis. The data collected from heavy metals analysis was statistical analyzed by analysis of variance (ANOVA) and Duncan's multiple range tests ${ }^{5}$ to find out significant level among fish tissues using statistical package IBM SPSS Statistics Version 21

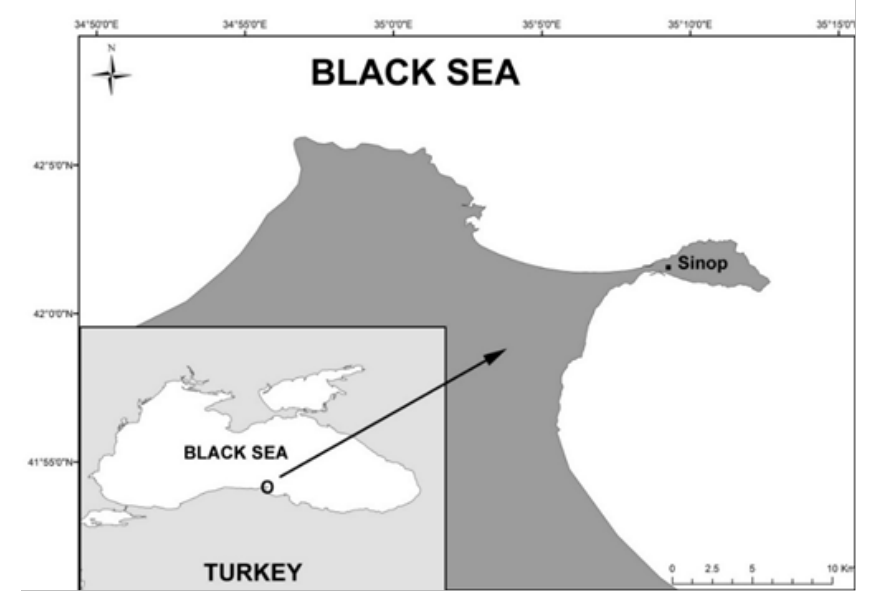

Figure I Study areain Sinop shores of the southern Black Sea.

The daily intakes of the toxic metals from the consumption of golden grey mullet were estimated for infant, children, and adults. The estimated daily intake (EDI) depends on both the toxic metal concentrations and the amount of consumption of fish. The EDI of toxic metals was determined using the equation below:

$$
\mathrm{EDI}=\frac{\mathrm{C}_{\text {metal }} \times \mathrm{W}_{\text {fish }}}{\mathrm{BW}}
$$


Where: $\mathrm{C}_{\text {metal }}$ is the concentration of metals in fish; $\mathrm{W}_{\text {fish }}$ represents the daily average consumption of fish is given as : $0.013,0.027$, and $0.041 \mathrm{~kg} /$ day for infants, children and adults respectively (UNSCEAR, 2010); BW is the body weight of $10 \mathrm{~kg}$ for infants, $30 \mathrm{~kg}$ for children and $70 \mathrm{~kg}$ for adults.

Hazard index (HI) were also calculated to determine the health risks due to the consumption of golden grey mullet contaminated with the toxic metals. Risk from metals intake through ingestion may be characterized using a hazard index (HI) as the ratio of the estimated metal dose (EDI $\mathrm{mg} / \mathrm{kg}$ of body wt. per day) and the reference dose (Rf. D mg/kg. y). The HI was calculated by using the equation below:

$$
\mathrm{HI}=\frac{\mathrm{EDI}}{\mathrm{Rf} . \mathrm{D}}
$$

If HI $>1.0$, then the EDI of a particular toxic metal exceeds the Rf.
$\mathrm{D}$, indicating that there is a potential risk associated with that toxic metal.

\section{Results}

Minimum size allowed for fishing is $20 \mathrm{~cm} .{ }^{4}$ In the current work, the mean length and weight of $C$. auratus were $35 \pm 5 \mathrm{~cm}$ and $310 \pm 20 \mathrm{~g}$. The recovery percentages results ranged from 95 to $102 \%$. Mean amounts ( $\mathrm{mg} / \mathrm{kg} \pm \mathrm{SD}$ wet wt.) of non-essential toxic metals in fish tissues are presented in Figure 2.

The EDIs of $\mathrm{Pb}, \mathrm{Hg}$ and $\mathrm{Cd}$ were estimated the mean of metal in edible tissues of C. auratus and the mean consumption of this fish per day for infants, children and adults, respectively as suggested by $\mathrm{UNSCEEAR} .{ }^{6}$ EDIs and HIs of $\mathrm{Pb}, \mathrm{Hg}$ and $\mathrm{Cd}$ were presented in Table 1.

Table I Mean amounts (mg/kg wet wt.), EDls and Hls of toxic metals in C. auratus due to ingestion of infants, children and adults

\begin{tabular}{|c|c|c|c|c|c|c|c|}
\hline \multirow{2}{*}{$\begin{array}{l}\text { Toxic } \\
\text { Metals }\end{array}$} & \multirow{2}{*}{$\begin{array}{l}\text { Rf. D } \\
\text { mg/day/ kg body wt. }\end{array}$} & \multicolumn{3}{|c|}{$\begin{array}{l}\text { EDI } \\
\text { mg/day/ kg body wt. }\end{array}$} & \multicolumn{3}{|c|}{ Hazard Index (HI) } \\
\hline & & Infants & Children & Adults & Infants & Children & Adults \\
\hline $\mathrm{Pb}$ & 0.004 & 0.0000793 & 0.0000549 & 0.000036 & 0.019825 & 0.013725 & 0.008932143 \\
\hline $\mathrm{Hg}$ & 0.0005 & 0.0000442 & 0.0000306 & 0.000019 & 0.0884 & 0.0612 & $0.03982857 \mid$ \\
\hline $\mathrm{Cd}$ & 0.001 & 0.0000195 & 0.0000135 & 0.0000087 & 0.0195 & 0.0135 & $0.0087857 \mid 4$ \\
\hline
\end{tabular}

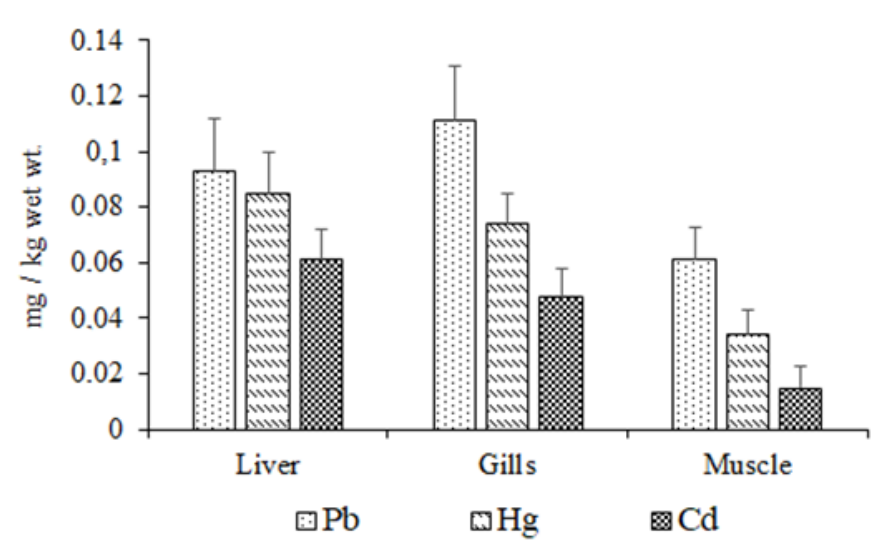

Figure 2 Toxic metal amounts with standard deviation in the liver, gills and edible tissues of golden grey mullet from Sinop shores of the southern Black Sea in 2016

\section{Discussion}

The results show that all the toxic three metal amounts in the edible dorsal muscles of $C$. auratus captured from Sinop shores of the southern Black Sea were lower than those in gills and liver.
Among studied toxic metals, $\mathrm{Pb}$ had highest mean concentration in gills compare to either liver or muscles. On the other hand highest amounts of $\mathrm{Hg}$ and $\mathrm{Cd}$ were observed in liver. In many studies, ${ }^{2}$ it was pointed out that liver was the principal detoxification route, and one of the most significant metal storage organs. Similarly, if the main entry route of the metal is through the water column, the highest amounts will be on gills. Non-essential heavy metals are highly toxic contaminants and their uptake and bioaccumulation in biota particularly beyond allowable limits may reason serious result directly on food chain and eventually to people. In the current work, the mean amounts of $\mathrm{Pb}, \mathrm{Hg}$ and $\mathrm{Cd}$ in the edible tissues of $C$. auratus were $0.061 \pm 0.012,0.034 \pm 0.009$ and $0.015 \pm 0.008 \mathrm{mg} / \mathrm{kg}$ wet wt., respectively. $\mathrm{Pb}, \mathrm{Hg}$ and $\mathrm{Cd}$ are toxic metal in fish, the presence of this metal in fish may cause risk on human health. They are harmful to human health even at low concentrations. According to $\mathrm{EC}^{7}$ and $\mathrm{TFC}^{8}$ the maximum permitted limits of $\mathrm{Pb}, \mathrm{Hg}$ and $\mathrm{Cd}$ are $0.3,0.5$ and $0.05 \mathrm{mg} / \mathrm{kg}$ wet wt., respectively. The current work reveals that consumption of golden grey mullet is safe. Accumulation of toxic metals in fish tissues appears to be a location specific phenomenon, depending upon some aquatic parts like water, plankton and detritus. Golden grey mullet feeds on planktonic organisms, snails, insects, small benthic organisms and detritus. ${ }^{4,9-14}$ The toxic metal amounts in mullet species from the Black Sea coasts were compared with other studies (Table 2). 
Table 2 Comparison of the amounts of toxic metals in mullet species from the Black Sea coasts

\begin{tabular}{|c|c|c|c|c|c|c|c|}
\hline \multirow{2}{*}{ Species } & \multirow{2}{*}{ Location } & \multirow{2}{*}{$\begin{array}{l}\text { Wet or Dry } \\
\text { wt. }\end{array}$} & \multirow{2}{*}{ Tissue } & \multicolumn{3}{|l|}{ Metals } & \multirow{2}{*}{ Ref } \\
\hline & & & & $\mathbf{P b}$ & $\mathbf{H g}$ & Cd & \\
\hline Mugil cephalus & Black Sea (Sinop) & Wet wt. & muscle & $0.09-0.19$ & - & $0.02-0.03$ & 10 \\
\hline Mugil cephalus & Black Sea (Pazar) & Dry wt. & muscle & $2.22 \pm 0.89$ & - & $<0.02$ & II \\
\hline Mugil cephalus & Black Sea & Wet wt. & muscle & $0.68 \pm 0.05$ & $0.070 \pm 0.004$ & $0.35 \pm 0.03$ & 12 \\
\hline \multirow{4}{*}{ Mugil cephalus } & \multirow{2}{*}{ Black Sea (Giresun) } & & muscle & $0.02 \pm 0.01$ & - & $0.57 \pm 0.27$ & \multirow{4}{*}{13} \\
\hline & & & liver & $0.44 \pm 0.7$ & - & $0.89 \pm 0.33$ & \\
\hline & \multirow{2}{*}{ Black Sea (Rize) } & & muscle & $0.90 \pm 0.32$ & - & $0.30 \pm 0.17$ & \\
\hline & & & liver & $3.33 \pm 1.77$ & - & $0.44 \pm 0.18$ & \\
\hline Mugil cephalus & Black Sea & Dry wt. & muscle & $0.61 \pm 0.04$ & - & $0.45 \pm 0.03$ & 14 \\
\hline \multirow{4}{*}{ Mugil cephalus } & \multirow{2}{*}{ Bulgaria (Varna Lake) } & & muscle & $0.07 \pm 0.01$ & $0.08 \pm 0.01$ & $0.024 \pm 0.002$ & \multirow{4}{*}{15} \\
\hline & & Wet wt. & gills & $0.08 \pm 0.02$ & $0.12 \pm 0.02$ & $0.031 \pm 0.003$ & \\
\hline & \multirow{2}{*}{ Bulgaria (Nesebar) } & & muscle & $0.05 \pm 0.01$ & $0.05 \pm 0.01$ & $0.012 \pm 0.002$ & \\
\hline & & & gills & $0.07 \pm 0.01$ & $0.06 \pm 0.01$ & $0.013 \pm 0.002$ & \\
\hline \multirow{2}{*}{ Mugil cephalus } & \multirow{2}{*}{ Bulgaria } & \multirow{2}{*}{ Wet wt. } & muscle & $0.05 \pm 0.01$ & $0.05 \pm 0.01$ & $0.012 \pm 0.002$ & \multirow{2}{*}{16} \\
\hline & & & gills & $0.07 \pm 0.01$ & $0.06 \pm 0.01$ & $0.013 \pm 0.002$ & \\
\hline Mugil sp. & Black Sea & Dry wt. & muscle & 0.023 & 0.11 & $<0.001$ & 17 \\
\hline Mugil soiuy & Black Sea (Sinop) & Wet wt. & muscle & $0.23 \pm 0.07$ & - & $<0.01 \pm 0.00$ & 18 \\
\hline Liza aurata & Black Sea (Sinop) & Wet wt. & muscle & $<0.05$ & $<0.05$ & $<0.02$ & 19 \\
\hline Liza ramada & Black Sea & Dry wt. & muscle & $0.07 \pm 0.01$ & $0.06 \pm 0.01$ & $0.02 \pm 0.01$ & 20 \\
\hline
\end{tabular}

In general, the results of this work are lower than the other studies in Table 2. Mean values of $\mathrm{Pb}$ and $\mathrm{Cd}$ in the edible tissues are in agreement with findings by other researchers ${ }^{15,16-19}$ and are lower than those obtained by ${ }^{20}$ in mullet species from the Black Sea shores. The indicated variability of metal concentration in mullet species depends on their habitats. They are pelagic species migrate frequently between saltwater, estuaries and freshwater. The fish species studied in Table 2 were obtained from different shores of the Black Sea at different times. These results confirm that the differences in metal concentration in various fish species could considerably be attributed to the differences in feeding habits and seasons. It may be suggested that feeding manners, seasons and different coastal areas play major role in the control of metal accumulation. Commercial fish species have been considered very good bio-indicators for heavy metal pollution in marine ecosystems because they occupy different trophic levels. Meanwhile, fish are widely consumed in the Black Sea coasts by humans.

\section{Conclusion}

The results of this work show that toxic metals amounts in the edible tissues of $C$. auratus are not exceeded the permissible limits set for metals by European regulation and Turkish food codex. The EDI of $\mathrm{Pb}, \mathrm{Hg}$ and $\mathrm{Cd}$ were estimated the means of these toxic metals in the edible tissues of $C$. auratus and the mean consumption of this fish per day for infants, children and adults, respectively. It can be seen from the Table 1, the results are quite below the recommended amounts of $\mathrm{Pb}, \mathrm{Hg}$ and $\mathrm{Cd}^{21-23}$ Estimated $\mathrm{HI}$ of the toxic metals was under the value of 1 , thus these toxic metals in C. auratus do not hazard any apparent threat to the local people. ${ }^{24,25}$ In terms of consumption of golden grey mullet there was no health risk for humans during the fishing season in 2016 from Sinop shores of the southern Black Sea.

\section{Acknowledgements}

This work was carried out at the University of Sinop, Fisheries Faculty, and Department of Hydrobiology.

\section{Conflict of interest}

Author declares that there is no conflict of interest.

\section{References}

1. Bat L, Öztekin A, Şahin F, et al. An overview of the Black Sea pollution in Turkey. Med FAR. 2018;1(2):67-86.

2. Bat L. The Contamination Status of Heavy Metals in Fish from the Black Sea, Turkey and Potential Risks to Human Health. In: Sezgin M, Bat L, Ürkmez D, Arıcı E, Öztürk B, editors. Black Sea Marine Environment: The Turkish Shelf. Istanbul, Turkey: Turkish Marine Research Foundation (TUDAV); 2017:322-418

3. Official Journal of the European Union. Directives Directive 2008/56/Ec of The European Parliament and of the Council of 17 June 2008 establishing a framework for community action in the field of marine environmental policy (Marine Strategy Framework Directive). 2008;164:19-40.

4. Froese R, Pauly D, editors. FishBase. World Wide Web electronic publication. 2018

5. Zar JH. Biostatistical analysis. New Jersey: Prentice Hall, Int; 1984.

6. UNSCEAR (United Nations Scientific Committee on the Effects of Atomic Radiation) Sources and Effects of Ionizing Radiations, UNSCAR 2008 Report to General Assembly with Scientific Annexes Volume I. United Nations; 2010.

7. Commission Regulation (EC). Official Journal of the European Union. Setting maximum levels for certain contaminants in food stuffs. Commission Regulation (EC) No 1881/2006;364:5-24. 
8. TFC. Communiqué on maximum limits of contaminants in foodstuffs. Published in the Official Gazette: (in Turkish). (Notification No: 2008/26). 2008. 26879 p.

9. Muus BJ, Dahlstrøm P. Collins guide to the sea fishes of Britain and North-Western Europe. London; 1985.

10. Bat L, Sezgin M, Ustun F, et al. Heavy metal concentrations in ten species of fishes caught in Sinop coastal waters of the Black Sea, Turkey. Turkish Journal of Fisheries and Aquatic Sciences. 2012;12:371-376.

11. Topcuoglu S, Ergül HA, Baysal A, et al. Determination of radionuclide and heavy metal concentrations in biota and sediment samples from Pazar and Rize stations in the eastern Black Sea. Fresenius Environmental Bulletin. 2003;12(7):695-699.

12. Tuzen M. Toxic and essential trace elemental contents in fish species from the Black Sea, Turkey. Food and Chemical Toxicology. 2009;47(8):1785-1790.

13. Türkmen M, Akaydin A. Metal levels in tissues of commercially important fish species from south eastern Black Sea Coasts. Indian Journal of GeoMarine Sciences. 2017;46(11):2357-2360.

14. Uluozlu OD, Tuzen M, Mendil D, et al. Trace metal content in nine species of fish from the Black and Aegean Seas, Turkey. Food chemistry 2007;104(2):835-840.

15. Stancheva M, Makedonski L, Petrova E. Determination of heavy metals ( $\mathrm{Pb}, \mathrm{Cd}, \mathrm{As}$ and $\mathrm{Hg}$ ) in Black Sea grey mullet (Mugil cephalus). Bulg $J$ Agric Sci. 2013;1:30-34.

16. Makedonski L, Peycheva K, Stancheva M. Determination of heavy metals in selected black sea fish species. Food Control. 2017;72:313-318.
17. Watanabe I, Tanabe S. Trace element accumulation in 20 species of fishes from Lake Baikal, Caspian Sea, Black Sea and Japanese Coastal Waters. Journal of Environmental Chemistry. 2003;13(1):31-40.

18. Ateş A, Türkemn M, Tepe Y. Assessment of heavy metals in fourteen marine fish species of four Turkish Seas. Indian Journal of Geo-Marine Sciences. 2015;519-525

19. Bat L, Öztekin HC, Üstün F. Heavy metal levels in four commercial fishes caught in Sinop coasts of the Black Sea, Turkey. Turkish Journal of Fisheries and Aquatic Sciences. 2015;15:399-405.

20. Ergül HA, Aksan S. Evaluation of non-essential element and micronutrient concentrations in seafood from the Marmara and Black Seas. J. Black Sea/ Mediterranean Environment. 2013;19(3):312-331.

21. EFSA. Lead dietary exposure in the European population. EFSA Journal. 2012;10(7):59.

22. EFSA Panel on Contaminants in the Food Chain (CONTAM). Scientific Opinion on the risk for public health related to the presence of mercury and methylmercury in food. EFSA Journal. 2012;10(12):241.

23. EFSA. Cadmium dietary exposure in the European population. EFSA Journal. 2012;10(1):37.

24. USEPA (US Environmental Protection Agency). Risk Assessment Guidance for Superfund. Human Health Evaluation Manual (Part A), Interim Final. EPA 540/1-89/002. Washington, DC: United States Environmental Protection Agency; 1989.

25. USEPA (US Environmental Protection Agency). Guidance for Assessing Chemical Contamination Data for Use in Fish Advisories. Vol. II Risk Assessment and Fish Consumption Limits EPA/823-B94-004. Washington, DC: United States Environmental Protection Agency; 2000. 